Vol 4. No 1. Februari 2020

ISSN 2580-5029

\title{
Inventarisasi Tumbuhan Obat Yang Dimanfaatkan Oleh Masyarakat Desa Durian Pandaan Kabupaten Pesisir Selatan
}

\author{
Novi $^{*}$, Vivi Septrilia ${ }^{2}$ \\ 1,2STKIP PGRI Sumatera Barat, Padang, Indonesia \\ *novi.s3tia@gmail,com
}

\begin{abstract}
Utilization of natural plants as medicine is one of the skills that has been scarce found even some places only become a wisdom by the local community. The use of natural plants as traditional medicine by the Durian Pandaan villagers is still widely used for traditional medicine. Among the medicinal plants used, the scientific name of the plant is still unknown. The purpose of this study was to determine the types of medicinal plants used by the Durian village community. This study used a descriptive survey method with direct observation and field interviews with 3 herbalists. Samples that have been fielded can be directly photographed intact and identified. The results of research conducted in the village of Durian Pandaan obtained 77 species from 44 families. With the highest use value is Curcuma domestica
\end{abstract}

Keywords: Medicinal Plants, Traditional Medicine, Durian Pandaan

\begin{abstract}
ABSTRAK
Pemanfaatan tumbuhan alam sebagai pengobatan merupakan salah satu keahlian yang telah langka dijumpai bahkan beberapa tempat hanya menjadi sebuah kearifan oleh masyarakat setempat. Penggunaan tumbuhan alam sebagai obat tradisional oleh masyarakat desa Durian Pandaan sampai saat sekarang ini masih banyak dimanfaatkan untuk pengobatan tradisional. Diantara tumbuhan obat yang digunakan, masih belum diketahui nama ilmiah dari tumbuhan yang dimanfaatkan. Tujuan dari penelitian ini untuk mengetahui Jenis Tumbuhan Obat yang dimanfaatkan oleh masyarakat desa Durian. Penelitian ini menggunakan metode survei deskriptif dengan teknik observasi dan wawancara langsung kelapangan dengan 3 orang ahli tumbuhan obat (dukun). Sampel yang telah di dapat dilapangan langsung di foto utuh dan di identifikasi. Hasil penelitian yang dilakukan di desa Durian Pandaandidapatkanhasil 77 species dari 44familia. DengannilaigunatertinggiadalahCurcuma domestica
\end{abstract}

Keywords: Tumbuhan Obat, Obat Tradisional, Durian Pandaan 


\section{PENDAHULUAN}

Indonesia merupakan salah satu negara kepulauan terbesar di dunia yang memiliki keanekaragaman tumbuhan yang tinggi. Menurut (Bappenas, 2016) keanekaragaman tumbuhan Indonesia menduduki peringkat lima besar dunia. Menurut (Nurrani, 2013) hutan Indonesia menyimpan potensi tumbuhan obat sebanyak 30.000 jenis, diantaranya 940 jenis berkhasiat untuk obat, dimana sekitar 78\% masih diperoleh melalui pengambilan langsung.

Indonesia memiliki banyak jenis tumbuhan baik itu tumbuhan yang sengaja di budidayakan oleh masyarakat maupun tumbuhan yang tumbuh liar di hutan. Diantaranya terdapat tumbuhan yang berkhasiat sebagai obat dan telah digunakan sebagai pengobatan tradisional secara turun temurun yang masih dimanfaatkan hingga saat ini. Menurut (Dahlia, 2016) tumbuhan obat didefinisikan sebagai jenis tumbuhan yang sebagian, seluruh dan atau eksudat tumbuhan yang digunakan sebagai obat, bahan, atau ramuan obat.

Obat tradisional adalah ramuan bahan berupa tumbuhan, hewan, mineral, yang secara turun temurun telah digunakan untuk pengobatan. Masyarakat pedesaan khususnya yang bermukiman di sekitar kawasan hutan seringkali menggunakan tumbuhan alam untuk pengobatan (Umar, 2006). Pemanfaatan tumbuhan alam sebagai obat tradisional telah dipraktekkan oleh masyarakat di desa Durian Pandaan sejak dulu hingga saat ini, akan tetapi masyarakat setempat belum mengetahui nama ilmiah dari tumbuhan obat yang digunakan.

Tujuan penelitian ini adalah untuk mengetahui jenis tumbuhan obat yang dimanfaatkan oleh masyarakat desa Durian Pandaan

\section{METODE}

Penelitian ini dilakukan pada bulan Agustus 2019 di Desa Durian Pandaan Kabupaten Pesisir Selatan.Metode yang digunakan adala hsurvei deskriptif dengan teknik observasi dan wawancara langsung kelapangan dengan 3 orang dukun. Sampel yang telah di dapat dilapangan langsung di foto utuh dan di Identifikasi sampel di Laboratorium Botani.

Data dianalisis dengan menggunakan perhitungan Species Use value

$$
\mathrm{UVs}=\Sigma \mathrm{U} V \mathrm{is} / \mathrm{n} \mathrm{i}
$$

\section{Keterengan:}

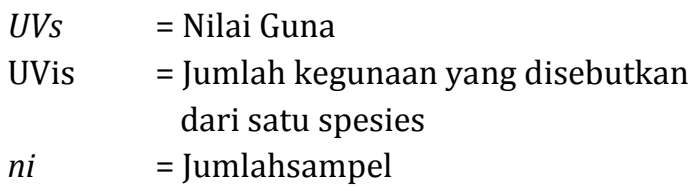

\section{HASIL DAN PEMBAHASAN}

Penggunaan dan cara pemakaian tumbuhan obat ini di peroleh masyarakat berdasarkan pengetahuan secara turun temurun dari leluhur, orang pintar (dukun), kenalan ataupun dari buku-buku tumbuhan obat yang dicoba dan cocok. Hasil penelitian telah teriventarisasi sebanyak 77 jenis tumbuhan obatdengan cara penggunaan yang berbedabeda (Tabel 1) 
Biotropic 2020, Vol. 4 (No.1): 40 - 47

Inventarisasi Tumbuhan Obat Yang Dimanfaatkan Oleh Masyarakat Desa Durian Pandaan Kabupaten Pesisir Selatan

Tabel1. Jenis tumbuhan obat dan bagian yang dimanfaatkan

\begin{tabular}{|c|c|c|c|c|c|}
\hline No & Familia & Spesies & Nama daerah & Nama Indonesia & $\begin{array}{l}\text { Bagian yang } \\
\text { dimanfaatkan }\end{array}$ \\
\hline 1. & Acanthaceae & $\begin{array}{l}\text { 1. Andrographis paniculata } \\
\text { (Burm.F.) Wall } \\
\text { 2. Justicia gendarussa Blanco. }\end{array}$ & $\begin{array}{l}\text { 1. Ampadu tanah } \\
\text { 2. Sugi-sugi }\end{array}$ & $\begin{array}{l}\text { 1. Sambiloto } \\
\text { 2. Gandarusa }\end{array}$ & $\begin{array}{ll}\text { 1. } & \begin{array}{l}\text { Seluruh } \\
\text { bagian }\end{array} \\
\text { 2. } & \begin{array}{l}\text { Seluruh } \\
\text { bagian }\end{array}\end{array}$ \\
\hline 2. & Agavaceae & 3. Cordyline terminalis Kunth. & 3. Yuang balik & 3. Andong & 3. Daun \\
\hline 3. & Alliaceae & $\begin{array}{l}\text { 4. Allium cepa } \mathrm{L} \text {. } \\
\text { 5. Allium sativum } \mathrm{L} \text {. }\end{array}$ & $\begin{array}{l}\text { 4. Bawang merah } \\
\text { 5. Bawang putih }\end{array}$ & $\begin{array}{l}\text { 4. Bawang merah } \\
\text { 5. Bawang putih }\end{array}$ & $\begin{array}{l}\text { 4. Umbi } \\
\text { 5. Umbi }\end{array}$ \\
\hline 4. & $\begin{array}{l}\text { Amaranthacea } \\
\mathrm{e}\end{array}$ & $\begin{array}{l}\text { 6. Alternanthera amoena L. } \\
\text { 7. Amaranthus spinosus L. }\end{array}$ & $\begin{array}{l}\text { 6. Bayam merah } \\
\text { 7. Bayam duri }\end{array}$ & $\begin{array}{l}\text { 6. Bayam merah } \\
\text { 7. Bayam duri }\end{array}$ & $\begin{array}{l}\text { 6. Daun } \\
\text { 7. Daun }\end{array}$ \\
\hline 5. & Annonaceae & $\begin{array}{l}\text { 8. Annona muricata L. } \\
\text { 9. Cananga odorata (Lam.) } \\
\text { Hook. F. \& Thomson }\end{array}$ & $\begin{array}{l}\text { 8. Durian } \\
\text { balando } \\
\text { 9. Nango }\end{array}$ & $\begin{array}{l}\text { 8. Sirsak } \\
\text { 9. Kenanga }\end{array}$ & $\begin{array}{l}\text { 8. Buah dan } \\
\text { daun } \\
\text { 9. Bunga }\end{array}$ \\
\hline 6. & Apiaceae & 10. Apium graveolens L. & 10. Seledri & 10. Seledri & $\begin{array}{l}\text { 10. Batang dan } \\
\text { daun }\end{array}$ \\
\hline 7. & Apocynaceae & $\begin{array}{l}\text { 11. Catharantus roseus (L.) } \\
\text { G.Don } \\
\text { 12. Tabernaemontana } \\
\text { divaricata (L.) R. Br. }\end{array}$ & $\begin{array}{l}\text { 11. Daun piriang- } \\
\text { piriang } \\
\text { 12. Melati }\end{array}$ & $\begin{array}{l}\text { 11. Tapak dara } \\
\text { 12. Melati }\end{array}$ & $\begin{array}{l}\text { 11. Daun } \\
\text { 12. Bunga }\end{array}$ \\
\hline 8. & Arecaceae & $\begin{array}{l}\text { 13. Areca catechu L. } \\
\text { 14. Arenga pinnata Merr. } \\
\text { 15. Cocos nucifera } \mathrm{L} .\end{array}$ & $\begin{array}{l}\text { 13. Pinang } \\
\text { 14. Anau } \\
\text { 15. Karambia }\end{array}$ & $\begin{array}{l}\text { 13. Pinang } \\
\text { 14. Aren } \\
\text { 15. Kelapa }\end{array}$ & $\begin{array}{l}\text { 13. Buah } \\
\text { 14. Getah } \\
\text { 15. Buah }\end{array}$ \\
\hline 9. & Aloaceae & 16. Aloe vera $\mathrm{L}$. & 16. Lidah buayo & 16. Lidah buaya & 16. Daun \\
\hline 10. & Asteraceae & $\begin{array}{l}\text { 17. Eclipta alba Miq } \\
\text { 18. Enhydra fluctuans Lour. } \\
\text { 19. Vernonia amygdalina Delile. }\end{array}$ & $\begin{array}{l}\text { 17. Urang aring } \\
\text { 18. Cikarau } \\
\text { 19. Daun afrika }\end{array}$ & $\begin{array}{l}\text { 17. Urang aring } \\
\text { 18. Daun cikarau } \\
\text { 19. Daun afrika }\end{array}$ & $\begin{array}{l}\text { 17. Daun } \\
\text { 18. Daun } \\
\text { 19. Daun }\end{array}$ \\
\hline 11. & Balsaminaceae & 20. Impatiens balsamina L. & 20. Pacar air & 20. Pacar air & 20. Daun \\
\hline 12. & Bromeliaceae & 21. Ananas comosus (L.) Merr. & 21. Naneh & 21. Nenas & 21. Buah \\
\hline 13. & $\begin{array}{l}\text { Caesalpiniacea } \\
\text { e }\end{array}$ & 22. Cassia Alata L. & 22. Sukagaduang & 22. Ketepeng Cina & 22. Daun \\
\hline 14. & Caricaceae & 23. Carica papaya L. & 23. Situka & 23. Рерауа & 23. Buah \\
\hline 15. & Clusiaceae & 24. Garcinia mangostana L. & 24. Manggih & 24. Manggis & 24. Kulit buah \\
\hline 16. & Costaceae & $\begin{array}{l}\text { 25. Costus speciosus (J.Koenig) } \\
\text { Sm. }\end{array}$ & 25. Sitawa & 25. Pacing tawar & 25. Daun \\
\hline 17. & Crassulaceae & $\begin{array}{l}\text { 26. Bryophyllum pinnatum } \\
\text { Kurz. }\end{array}$ & 26. Sidingin & 26. Cocor bebek & 26. Daun \\
\hline 18. & Cucurbitaceae & 27. Momordica charantia L. & 27. Pario & 27. Pare & 27. Buah \\
\hline 19. & Euphorbiaceae & $\begin{array}{l}\text { 28. Jatropha curcas } \mathrm{L} . \\
\text { 29. Jatropha multfida } \mathrm{L} . \\
\text { 30. Phyllanthus niruri L. }\end{array}$ & $\begin{array}{l}\text { 28. Daun jarak } \\
\text { 29. Betadin } \\
\text { 30. Dukuang anak }\end{array}$ & $\begin{array}{l}\text { 28. Jarak Pagar } \\
\text { 29. Jarak tintir/ } \\
\text { betadin } \\
\text { 30. Meniran }\end{array}$ & $\begin{array}{l}\text { 28. Daun } \\
\text { 29. Getah } \\
\text { 30. Seluruh } \\
\text { bagian }\end{array}$ \\
\hline 20. & Hippobroma & $\begin{array}{l}\text { 31. Hippobroma longiflora (L.) } \\
\text { G. Don }\end{array}$ & 31. Katarak & 31. Kitolot & 31. Bunga \\
\hline 21. & Lamiaceae & $\begin{array}{l}\text { 32. Coleus scutellariodes } \\
\text { L.Benth } \\
\text { 33. Ocimum basilicum L. } \\
\text { 34. Ocimum tenuiflorum L } \\
\text { 35. Orthosiphon stamineus } \\
\text { Benth }\end{array}$ & $\begin{array}{l}\text { 32. Piladang hitam } \\
\text { 33. Salasih } \\
\text { 34. Ruku-ruku } \\
\text { 35. Sunguik } \\
\quad \text { kucing }\end{array}$ & $\begin{array}{l}\text { 32. Iler } \\
\text { 33. Selasih } \\
\text { 34. Ruku-ruku } \\
\text { 35. Kumis kucing }\end{array}$ & $\begin{array}{l}\text { 32. Daun } \\
\text { 33. Daun } \\
\text { 34. Daun } \\
\text { 35. Daun }\end{array}$ \\
\hline 22. & Lauraceae & $\begin{array}{l}\text { 36. Cinnamomum verum J. Presl } \\
\text { 37. Persea americana Mill. }\end{array}$ & $\begin{array}{l}\text { 36. Kayu manih } \\
\text { 37. Pokat }\end{array}$ & $\begin{array}{l}\text { 36. Kayu manis } \\
\text { 37. Alpukat }\end{array}$ & $\begin{array}{l}\text { 36. Kulit kayu } \\
\text { 37. Buah }\end{array}$ \\
\hline 23. & Leguminosae & 38. Cassia tora $\mathrm{L}$ & $\begin{array}{l}\text { 38. Galinggang } \\
\text { lauik }\end{array}$ & 38. Ketepeng kecil & 38. Daun \\
\hline 24. & Lytraceae & 39. Lawsonia inermis L. & 39. Inai & 39. Pacar kuku & 39. Daun \\
\hline 25. & Malvaceae & $\begin{array}{l}\text { 40. Hibiscus rosa-sinensis } \mathrm{L} \text {. } \\
\text { 41. Hibiscus tiliaceus } \mathrm{L} . \\
\text { 42. Sida rhombifolia } \mathrm{L} .\end{array}$ & $\begin{array}{l}\text { 40. Bungo rayo } \\
\text { 41. Daun baru } \\
\text { 42. Sidaguri }\end{array}$ & $\begin{array}{l}\text { 40. Kembang } \\
\text { sepatu } \\
\text { 41. Daun waru } \\
\text { 42. Seleguri }\end{array}$ & $\begin{array}{l}\text { 40. Daun } \\
\text { 41. Daun } \\
\text { 42. Daun }\end{array}$ \\
\hline 26. & $\begin{array}{l}\text { Melastomatace } \\
\text { ae }\end{array}$ & $\begin{array}{l}\text { 43. Melastoma malabathricum } \\
\text { L. }\end{array}$ & 43. Sikaduduak & 43. Senggani & 43. Daun \\
\hline
\end{tabular}


Biotropic 2020, Vol. 4 (No.1): 40 - 47

Inventarisasi Tumbuhan Obat Yang Dimanfaatkan Oleh Masyarakat Desa Durian Pandaan Kabupaten Pesisir Selatan

\begin{tabular}{|c|c|c|c|c|c|}
\hline No & Familia & Spesies & Nama daerah & Nama Indonesia & $\begin{array}{l}\text { Bagian yang } \\
\text { dimanfaatkan }\end{array}$ \\
\hline 27. & Mimosaceae & 44. Mimosa pudica L. & 44. Sikajuik & 44. Putri malu & $\begin{array}{l}\text { 44. Seluruh } \\
\text { bagian }\end{array}$ \\
\hline 28. & Moraceae & $\begin{array}{l}\text { 45. Artocarpus heterophyllus } \\
\text { Lam. }\end{array}$ & 45. Cubadak & 45. Nangka & 45. Buah \\
\hline 29. & Musaceae & 46. Musa paradiciaca $\mathrm{L}$. & 46. Pisang & 46. Pisang & $\begin{array}{l}\text { 46. Batang dan } \\
\text { buah }\end{array}$ \\
\hline 30. & Myristicaceae & 47. Myristica fragrans Houtt. & 47. Palo & 47. Pala & 47. Buah \\
\hline 31. & Myrtaceae & $\begin{array}{l}\text { 48. Psidium guajava L. } \\
\text { 49. Syzygium aromaticum L. } \\
\text { Merr, \& L. M. Perry. } \\
\text { 50. Syzygium polyanthum Miq. }\end{array}$ & $\begin{array}{l}\text { 48. Piaweh } \\
\text { 49. Cengkeh } \\
\text { 50. Daun salam }\end{array}$ & $\begin{array}{l}\text { 48. Jambu biji } \\
\text { 49. Cengkeh } \\
\text { 50. Daun salam }\end{array}$ & $\begin{array}{l}\text { 48. Daun dan } \\
\text { buah } \\
\text { 49. Buah } \\
\text { 50. Daun }\end{array}$ \\
\hline 32. & Oxalidaceae & $\begin{array}{l}\text { 51. Averrhoa bilimbi L. } \\
\text { 52. Averrhoa carambola L. }\end{array}$ & $\begin{array}{l}\text { 51. Asam tunjuk } \\
\text { 52. Asam sewa }\end{array}$ & $\begin{array}{l}\text { 51. Belimbing } \\
\text { sayur } \\
\text { 52. Belimbing } \\
\text { manis }\end{array}$ & $\begin{array}{l}\text { 51. Buah } \\
\text { 52. Buah, } \\
\text { bunga }\end{array}$ \\
\hline 33. & Pandanaceae & $\begin{array}{l}\text { 53. Pandanus amaryllifolius } \\
\text { Roxb. }\end{array}$ & 53. Pandan & 53. Pandan wangi & 53. Daun \\
\hline 34. & Phyllanthaceae & 54. Sauropus androgynus Merr. & 54. Pucuk katu & 54. Katuk & 54. Daun \\
\hline 35. & Piperaceae & $\begin{array}{l}\text { 55. Peperomia pellucida (L.) } \\
\text { Kunt. } \\
\text { 56. Piper betle L. }\end{array}$ & $\begin{array}{l}\text { 55. Rumpuik sirih } \\
\text { 56. Sirih hijau }\end{array}$ & $\begin{array}{l}\text { 55. Suruhan } \\
\text { 56. Sirih hijau }\end{array}$ & $\begin{array}{l}\text { 55. Seluruh } \\
\text { bagian } \\
\text { 56. Daun }\end{array}$ \\
\hline 36. & Poaceae & $\begin{array}{l}\text { 57. Cymbopogon citratus Stapf. } \\
\text { 58. Imperata cylindrica L. }\end{array}$ & $\begin{array}{l}\text { 57. Sarai } \\
\text { 58. Alang-alang }\end{array}$ & $\begin{array}{l}\text { 57. Sereh } \\
\text { 58. Alang-alang }\end{array}$ & $\begin{array}{l}\text { 57. Seluruh } \\
\text { bagian } \\
\text { 58. Seluruh } \\
\text { bagian }\end{array}$ \\
\hline 37. & Portulacaceae & $\begin{array}{l}\text { 59. Portulaca oleracea L. } \\
\text { 60. Talinum paniculatum [Jacq.] } \\
\text { Gaertn. }\end{array}$ & $\begin{array}{l}\text { 59. Rumpuik iduik } \\
\text { 60. Gingseng }\end{array}$ & $\begin{array}{l}\text { 59. Krokot } \\
\text { 60. Som jawa }\end{array}$ & $\begin{array}{l}\text { 59. Seluruh } \\
\text { bagian } \\
\text { 60. Daun }\end{array}$ \\
\hline 38. & Rosaceae & 61. Rosa alba L. & 61. Mawar putih & 61. Mawar putih & 61. Bunga \\
\hline 39. & Rubiaceae & $\begin{array}{l}\text { 62. Coffea robusta L.Linden } \\
\text { 63. Gardenia jasminoides J. Ellis } \\
\text { 64. Morinda citrifolia L. }\end{array}$ & $\begin{array}{l}\text { 62. Kopi } \\
\text { 63. Kacang piriang } \\
\text { 64. Mengkudu }\end{array}$ & $\begin{array}{l}\text { 62. Kopi } \\
\text { 63. Kaca piring } \\
\text { 64. Mengkudu }\end{array}$ & $\begin{array}{l}\text { 62. Buah } \\
\text { 63. Daun } \\
\text { 64. Buah }\end{array}$ \\
\hline 40. & Rutaceae & $\begin{array}{l}\text { 65. Citrus aurantiifolia } \\
\text { (Christm.) Swinge. } \\
\text { 66. Citrus hystrix Dc. } \\
\text { 67. Clausena excavata Burm.f. }\end{array}$ & $\begin{array}{l}\text { 65. Asam kapeh } \\
\text { 66. Asam puruik } \\
\text { 67. Sicerek }\end{array}$ & $\begin{array}{l}\text { 65. Jeruk nipis } \\
\text { 66. Jeruk purut } \\
\text { 67. Salam koja }\end{array}$ & $\begin{array}{l}\text { 65. Buah } \\
\text { 66. Buah } \\
\text { 67. Daun }\end{array}$ \\
\hline 41. & Sapindaceae & $\begin{array}{l}\text { 68. Nephelium lappaceum } \\
\text { (Hiern) Leenh. }\end{array}$ & 68. Rambutan & 68. Rambutan & 68. Daun \\
\hline 42. & Solanaceae & $\begin{array}{l}\text { 69. Physalis angulata } \mathrm{L} \text {. } \\
\text { 70. Solanum torvum Schltdl. } \\
\text { 71. Solanum lycopersicum L. }\end{array}$ & $\begin{array}{l}\text { 69. Latuik-latuik } \\
\text { 70. Rimbang } \\
\text { 71. Tomat }\end{array}$ & $\begin{array}{l}\text { 69. Ciplukan } \\
\text { 70. Rimbang } \\
\text { 71. Tomat }\end{array}$ & $\begin{array}{l}\text { 69. Seluruh } \\
\text { bagian } \\
\text { 70. Buah } \\
\text { 71. Buah }\end{array}$ \\
\hline $\begin{array}{l}43 . \\
44 .\end{array}$ & $\begin{array}{l}\text { Thymelaeaceae } \\
\text { Zingiberaceae }\end{array}$ & $\begin{array}{l}\text { 72. Phaleria macrocarpa Boerl. } \\
\text { 73. Alpinia galanga Willd. } \\
\text { 74. Curcuma longa L. } \\
\text { 75. Kaempferia galanga L. } \\
\text { 76. Zingiber purpureum Roscoe. } \\
\text { 77. Zingiber officinale } \text { Roscoe. }\end{array}$ & $\begin{array}{l}\text { 72. Mahkota dewa } \\
\text { 73. Langkueh } \\
\text { 74. Kunyik } \\
\text { 75. Cakua } \\
\text { 76. Kunyit erang } \\
\text { 77. Sipadeh }\end{array}$ & $\begin{array}{l}\text { 72. Mahkota dewa } \\
\text { 73. Lengkuas } \\
\text { 74. Kunyit } \\
\text { 75. Kencur } \\
\text { 76. Bengle } \\
\text { 77. Jahe }\end{array}$ & $\begin{array}{l}\text { 72. Buah } \\
\text { 73. Rimpang } \\
\text { 74. Rimpang } \\
\text { 75. Rimpang } \\
\text { 76. Rimpang } \\
\text { 77. Rimpang }\end{array}$ \\
\hline
\end{tabular}

Hasil penelitian di Desa Durian

Pandaan Kabupaten Pesisir Selatan

didapatkan sebanyak $77 \quad$ spesies

tumbuhan obat yang terdiri dari 44 famili.

Famili tumbuhan terbanyak yang

dimanfaatkan sebagai obat-obatan adalah

dari familia Zingiberaceae sebanyak 5 spesies, yaitu Lengkuas (Alpinia galanga Willd.), Kunyit (Curcuma longa L.), Kencur (Kaempferia galanga L.), Jahe (Zingiberofficinale Roscoe.), Bengle (Zingiber purpureumRoscoe). Spesies tumbuhan yang paling banyak digunakan yaitu kunyit (Curcuma longaL.). Hal ini 
Biotropic 2020, Vol. 4 (No.1): $40-47$

Inventarisasi Tumbuhan Obat Yang Dimanfaatkan Oleh Masyarakat Desa Durian Pandaan Kabupaten Pesisir

Selatan

disebabkan karena kunyit banyak mengandung khasiat yang dapat dimanfaatkan oleh masyarakat sebagai obat dan ampuh dalam menyembuhkan berbagai penyakit. Menurut (Shan \& Iskandar, 2018) kunyit memiliki kandungan kimia yang sangat penting seperti kurkumin, minyak atsiri, resin, desmetoksikurkumin, oleoreson dan bidesmetoksikurkumin.

Hasil penelitian ini sejalan dengan hasil penelitian Mabel et. Al tentang identifikasi dan pemanfaatan tumbuhan obat suku Dani di Kabupaten Jayawijaya Papua diperoleh family zingiberaceae paling banyak dimantaafkan sebagai tumbuhan obat.

Organ yang dimanfaatkan umumnya adalah akar, batang, umbi, daun, tangkai buah dan bunga.D ari organ tersebut yang paling banyak dimanfaatkan adalah daun. Hal ini disebabkan bagian daun merupakan bagian yang sangat mudah dijumpai dan selalu tersedia. Pemanfaatan dan pengambilannya tergolong mudah dan sederhana. Selain itu karena khasiat daun diketahui secara turun temurun lebih banyak dalam segi penyembuhannya dibandingkan dengan bagian yang lain.

Penelitian ini sejalan dengan penelitian yang dilakukan Mesfin (2013) tentang Studi etnobotani tanaman obat tradisional yang dimanfaatkan oleh penduduk asli daerah Gemad, Ethiopia

Utara diperoleh hasil bahwa bagian tumbuhan yang paling banyak dimanfaatkan adalah daun.

Menurut Patimah (2010) pada daun diduga banyak terakumulasi senyawa metabolit sekunder yang berguna sebagai obat seperti tannin, alkaloid, minyak atsiri dan senyawa organik lainnya yang tersimpan dalam vakuola ataupun pada jaringan tambahan seperti trikoma

. Ditambahkan oleh Savitri (2015), keuntungan penggunaan daun sebagai bahan obat karena daun memiliki serat yang lunak sehingga mudah mengekstrak zat-zat tersebut. Menurut (Harborne, 1987) daun merupakan bagian dari tumbuhan yang mengandung senyawa metabolit sekunder berupa alkaloid, flavonoid, steroid, saponin, terpenoiddan tannin. Metabolit sekunder ini bersifat spesifik dan banyak ditemukan pada daun danmerupakan biomolekul yang dapat digunakan sebagai komponen dalam penemuan dan pengembangan obat-obat baru.

Setiap jenis tumbuhan memiliki cara pengolahan dan kegunaanmasing-masing. Ada jenis tumbuhan yang cara penggunaannya tunggal dan ada yang diramu dengan tumbuhan lainnya. Cara pengolahan obat yang dimanfaatkan yaitu direbus, diseduh, diperas, ditumbuk, dioles, dibalut, dimandikan, ditetes. Masyarakat desa Durian Pandaan sendiri cara pengolahan tumbuhan yang lebih 
Biotropic 2020, Vol. 4 (No.1): 40 - 47

Inventarisasi Tumbuhan Obat Yang Dimanfaatkan Oleh Masyarakat Desa Durian Pandaan Kabupaten Pesisir Selatan

banyak digunakan yaitu dengan cara direbus.

Menurut (Susila, Tellu, \& Tangge, 2017) umumnya masyarakat di Desa Tinading dalam menggunakan tanaman untuk bahan obat masih sangat tradisional berdasarkan pengetahuan yang diperoleh dari orang tua maupun kerabat lain.

Nilai manfaat (Use value) merupakan metode yang digunakan untuk melihat nilai kepentingan dari pengguna setiap spesies tumbuhan obat berdasarkan hasil wawancara dengan dukun setempat. Dari hasil perhitungan ini dapat diketahui jenis spesies tumbuhan manakah yang paling banyak digunakan atau yang paling bermanfaat dalamm pengobatan tradisional (Wanti, 2017)

Untuk mengetahui nilai kepentingan atau nilai manfaat dari suatu tumbuhan berdasarkan informasi dari beberapa dukun dapat diketahui nilainya dengan menggunakan rumus Use value, dapat dilihat pada Tabel 2 .

Tabel 2. Nilai manfaat (Use Value) tumbuhan yang digunakan oleh masyarakat desa Durian Pandaan

\begin{tabular}{|c|c|c|c|}
\hline No & Species & Jumlah & $\begin{array}{c}\text { Nilai manfaat } \\
\text { (Use value) }\end{array}$ \\
\hline 1 & Averrhoa carambola L. & 9 & 0,050 \\
\hline 2 & Curcuma longa $\mathrm{L}$. & 7 & 0,065 \\
\hline 3 & Cocos nucifera Linn. & 6 & 0,043 \\
\hline 4 & Cinnamomum verumJ. Presl & 4 & 0,028 \\
\hline 5 & Zingiber officinale Roscoe & 4 & 0,028 \\
\hline 6 & Piper betle L. & 4 & 0,028 \\
\hline 7 & Andrographis paniculata (Burm.F.) Wall & 4 & 0,028 \\
\hline 8 & Zingiber purpureum Roscoe. & 4 & 0,028 \\
\hline 9 & Portulaca oleracea L. & 4 & 0,028 \\
\hline 10 & Kaempferia galanga L. & 3 & 0,021 \\
\hline 11 & Cassia Alata L. & 3 & 0,021 \\
\hline 12 & Physalis angulata L. & 3 & 0,021 \\
\hline 13 & Portulaca oleracea L. & 3 & 0,021 \\
\hline 14 & Sida rhombifolia L. & 3 & 0,021 \\
\hline 15 & Pandanus amaryllifolius Roxb. & 2 & 0,014 \\
\hline 16 & Talinum paniculatum [Jacq.] Gaertn. & 2 & 0,014 \\
\hline 17 & Alternanthera amoena L. & 2 & 0,014 \\
\hline 18 & Carica papaya $\mathrm{L}$. & 2 & 0,014 \\
\hline 19 & Mimosa pudica L. & 2 & 0,014 \\
\hline 20 & Cordyline terminalis Kunth. & 2 & 0,014 \\
\hline 21 & Arenga pinnata Merr. & 2 & 0,014 \\
\hline 22 & Citrus aurantiifolia (Christm.) Swinge. & 2 & 0,014 \\
\hline 23 & Alpinia galanga Willd. & 2 & 0,014 \\
\hline 24 & Coleus scutellariodes L.Benth & 2 & 0,014 \\
\hline 25 & Nephelium lappaceum (Hiern) Leenh. & 2 & 0,014 \\
\hline 26 & Hibiscus rosa-sinensisL. & 2 & 0,014 \\
\hline 27 & Garcinia mangostana L. & 2 & 0,014 \\
\hline 28 & Cassia tora $\mathrm{L}$. & 2 & 0,014 \\
\hline 29 & Momordica charantia L. & 2 & 0,014 \\
\hline 30 & Jatropha curcas L. & 1 & 0,007 \\
\hline
\end{tabular}


Biotropic 2020, Vol. 4 (No.1): 40 - 47

Inventarisasi Tumbuhan Obat Yang Dimanfaatkan Oleh Masyarakat Desa Durian Pandaan Kabupaten Pesisir Selatan

\begin{tabular}{|c|c|c|c|}
\hline No & Species & Jumlah & $\begin{array}{c}\text { Nilai manfaat } \\
\text { (Use value) }\end{array}$ \\
\hline 31 & Lawsonia inermis L. & 1 & 0,007 \\
\hline 32 & Hibiscus tiliaceus L. & 1 & 0,007 \\
\hline 33 & Artocarpus heterophyllus Lam. & 1 & 0,007 \\
\hline 34 & Sauropus androgynus Merr. & 1 & 0,007 \\
\hline 35 & Peperomia pellucida(L.) Kunt. & 1 & 0,007 \\
\hline 36 & Gardenia jasminoides J. Ellis & 1 & 0,007 \\
\hline 37 & Solanum torvum Schltdl. & 1 & 0,007 \\
\hline 38 & Phaleria macrocarpa Boerl. & 1 & 0,007 \\
\hline 39 & Myristica fragrans Houtt. & 1 & 0,007 \\
\hline 40 & Phyllanthus niruri L. & 1 & 0,007 \\
\hline 41 & Allium cepa $\mathrm{L}$. & 1 & 0,007 \\
\hline 42 & Psidium guajava L. & 1 & 0,007 \\
\hline 43 & Clausena excavata Burm.f. & 1 & 0,007 \\
\hline 44 & Costus speciosus (J.Koenig) Sm. & 1 & 0,007 \\
\hline 45 & Bryophyllum pinnatum Kurz. & 1 & 0,007 \\
\hline 46 & Enhydra fluctuans Lour. & 1 & 0,007 \\
\hline 47 & Coffea robusta L.Linden & 1 & 0,007 \\
\hline 48 & Areca catechu L. & 1 & 0,007 \\
\hline 49 & Aloe vera $\mathrm{L}$. & 1 & 0,007 \\
\hline 50 & Vernonia amygdalina Delile. & 1 & 0,007 \\
\hline 51 & Ocimum basilicum L. & 1 & 0,007 \\
\hline 52 & Syzygium polyanthum Miq. & 1 & 0,007 \\
\hline 53 & Citrus hystrix Dc. & 1 & 0,007 \\
\hline 54 & Persea americana Mill. & 1 & 0,007 \\
\hline 55 & Ananas comosus (L.) Merr. & 1 & 0,007 \\
\hline 56 & Allium sativum L. & 1 & 0,007 \\
\hline 57 & Annona muricata L. & 1 & 0,007 \\
\hline 58 & Orthosiphon stamineus Benth & 1 & 0,007 \\
\hline 59 & Ocimum tenuiflorum $\mathrm{L}$ & 1 & 0,007 \\
\hline 60 & Melastoma malabathricum L. & 1 & 0,007 \\
\hline 61 & Jatropha multfida L. & 1 & 0,007 \\
\hline 62 & Syzygium aromaticum L. Merr, \& L. M. Perry. & 1 & 0,007 \\
\hline 63 & Cymbopogon citratus Stapf. & 1 & 0,007 \\
\hline 64 & Eclipta alba Miq & 1 & 0,007 \\
\hline 65 & Hippobroma longiflora (L.) G. Don & 1 & 0,007 \\
\hline 66 & Justicia gendarussa Blanco. & 1 & 0,007 \\
\hline 67 & Amaranthus spinosus L. & 1 & 0,007 \\
\hline 68 & Catharantus roseus (L.) G.Don & 1 & 0,007 \\
\hline 69 & Impatiens balsamina L. & 1 & 0,007 \\
\hline 70 & Tabernaemontana divaricata (L.) R. Br. & 1 & 0,007 \\
\hline 71 & Morinda citrifolia $\mathrm{L}$. & 1 & 0,007 \\
\hline 72 & Apium graveolens $\mathrm{L}$. & 1 & 0,007 \\
\hline 73 & Solanum lycopersicum L. & 1 & 0,007 \\
\hline 74 & Musa paradiciaca L. & 1 & 0,007 \\
\hline 75 & Averrhoa bilimbi L. & 1 & 0,007 \\
\hline 76 & Cananga odorata (Lam.) Hook. F. \& Thomson & 1 & 0,007 \\
\hline \multicolumn{2}{|r|}{ Jumlah } & 138 & 0,97 \\
\hline
\end{tabular}

Berdasarkan tabel nilai manfaat terlihat bahwa Use value paling banyak adalah terdapat pada Curcuma longa L. dengan jumlah manfaat untuk tumbuhan obat ada 7 penyakit dengan presentase 0,050 , hal ini disebabkan karena kunyit (Curcuma Longa L.) banyak mengandung khasiat yang dapat dimanfaatkan oleh masyarakat sebagai obat 
dan ampuh dalam menyembuhkan berbagai penyakit.

Menurut Hofmann (2007) nilaigunaspesies "Spesies Use Value" (SUV) menggambarkan tingkat nilai guna spesies tanaman dalam mengobati suatu kategori penyakit .

\section{KESIMPULAN}

Tumbuhan yang dimanfaatkan oleh masyarakat desa Durian Pandaan sebagai obat yaitu sebanyak 77 species yang terdiri dari 44 familia

\section{DAFTAR PUSTAKA}

Bappenas. (2016). Indonesian Biodiversity Strategy and Action Plan 2015-2020.

Dahlia, S. I. (2016). Kajian Etnobotani Tumbuhan Obat Oleh Masyarakat Desa Jaya Mekar Kabupaten Bandung Barat. Skripsi Fakultas Keguruan Dan Ilu Pendidkan Universitas Pasundan, 15-40

Hoffman, B., and Gallaher, T. (2011). Importance Indices in ethnobotany. $A$ Journal of Plants, People, and Applied research5: 201-218..

Mabel, Y., Herni, S.,Roni, K. (2018). Identifikasi dan Pemanfaatan Tumbuhan Obat Suku Dani di Kabupaten Jayawijaya Papua. Jurnal MIPA Unsrat Online 5(2) halaman 103-107

Mesfin, K.,Gebru, T., Teklemichael, T. 2013. Ethnobotanical Study of Tradisional Medicinal Plants Used by Indigenous People of Gemad District, Northern Ethiopia.Journal of Medicinal Plants Studies 1(4) halaman 32-37

Nurrani, L. (2013). Pemanfaatan Tradisional Tumbuhan Alam Berkhasiat Obat Oleh
Masyarakat Di Sekitar Cagar Alam Tangale. Info BPK Manado, 3(1), 1-22.

Patimah, (2010). Keanekaragaman Tumbuhan Obat di Kawasan Hutan Gunung Sinabung Kabupaten Karo Sumatera Skripsi. Departemen Biologi Fakultas Matematika dan Ilmu Pengetahuan Alam Universitas Sumetera Utara. Medan

Savitri, A. (2016). Tanaman Ajaib Basmi Penyakit Dengan TOGA (Tanaman Obat Keluarga) (Cetakan Pe). Jakarta: Bibit Publisher, 2016.

Shan, C. Y., \& Iskandar, Y. (2018). Studi Kandungan Kimia dan Aktivitas Farmakologi Tanaman Kunyit ( Curcuma longa L.).JurnalFarmaka, 16, 547-555.

Susila, K. A., Tellu, A. T., \& Tangge, L. (2017). Jenis dan Pemanfaatan Tanaman Obat di Desa Tinading dan Pengembangan Sebagai Media Pembelajaran. E-JIP BIOL, 5(2), 60-70.

Umar, R. M. (2006). Keanekaragaman Spesies Tumbuhan Berhasiat Obat Yang Dimanfaatkan Masyarakat Desa Paselloreng, Kabupaten Wajo. Prosiding Seminar Nasional Pengelolaan Sumberdaya Dan Keanekaragaman Hayati Secara Berkelanjutan.

Wanti, Z. (2017). Studi etnobotani tumbuhan obat tradisional di daerah Malalak Kabupaten Agam Provinsi Sumatera Barat. Skripsi Fakultas Matematika Dan Ilmu Pengetahuan Alam Universitas Andalas. 